UDC: 615.035.2:613.81

Dojčinović B, i Banjac N.

Disulfiramska reakcija.

NČ UM Halo 194. 2019;_25(3):

151-154.

Rad primljen: 17.06.2019

Prihvaćen: 12.12.2019.

\author{
Korespodencija: \\ Nada Banjac \\ Služba HMP sa edukativnom \\ centrom, \\ JZU Dom zdravlja Banja Luka \\ Sime Matavulja bb \\ 78000 Banja Luka \\ Republika Srpska, BIH \\ E-mail: \\ hitnanac@domzdravljabanjaluka.com
}

\section{PRIKAZ BOLESNIKA}

\section{DISULFIRAMSKA REAKCIJA}

Nada BANJAC, Boris DOJČINOVIĆ

Služba hitne medicinske pomoći sa edukativnom centrom, JZU Dom zdravlja

Banja Luka, Republika Srpska, Bosna i Hercegovina

\begin{abstract}
SAŽETAK
Disulfiram je lijek koji se koristi u terapiji odvikavanja od alkohola. Reakcija na relaciji disulfiram-etanol nastaje kao posljedica povišenih vrijednosti serumskog acetaldehida, koji nastaje kao proizvod metabolizma etanola u jetri oksidisanog od strane alkoholne dehidrogenaze, a u daljem toku, aldehidna dehidrogenaza oksidiše acetaldehid do acetata koji se eliminiše iz organizma. Disulfiram blokira ovaj enzim te izaziva porast koncentracije acetaldehida u serumu, nakon konzumiranja etanola, te se u tom slučaju javlja odbojnost prema alkoholu zbog posljedične mučnine, vrtoglavice i nagona za povraćanjem. Prikazujemo 31-godišnjeg pacijenta, koji je zbog hroničnog alkoholizma, a u cilju odvikavanja od alkohola, bio na terapiji disulfiramom. Trideset minuta prije pregleda u Službi hitne medicinske pomoći konzumirao je veću količinu alkohola. Tokom pregleda na osnovu ispoljenih simptoma: agitiranost, tahikardija, hipotenzija, crvenilo kože po tipu urtikarije, postavljena je dijagnoza disulfiramske reakcije, nakon čega je radi dodatne dijagnostike $\mathrm{i}$ produžene opservacije transportovan na viši referenti nivo $u$ Univerzitetski klinički centar Banja Luka. Tokom transporta, ordiniran je kiseonik, uspostavljen intravenski put i primijenjena infuziona fiziološka otopina $\mathrm{NaCl}$, kortikosteroidi i analgetik. Pacijent je sve vrijeme bio na kontinuiranom EKG monitoringu. Ljekari hitne medicinske pomoći moraju biti edukovani o načinu prepoznavanja i inicijalnoj terapiji disulfiramske reakcije kod osoba koje su uključene u program odvikavanja od alkohola.
\end{abstract}

Ključne riječi: alkoholizam, disulfiram, acetaldehid.

\section{Uvod}

Disulfiram (tetraethylthiuram disulfide (TETD) je lijek koji se koristi kao pomoć u toku terapije hroničnog alkoholizma i odvikavanje od alkohola. Uočeno je da je lijek izuzetno efikasan kada se uzima pravilno. Ovo je prvi lijek koji je odobren od američke Uprave za hranu i lekove (FDA) za liječenje hroničnog alkoholizma 1951. godine [1]. Etanol je jedna od najupotrebljavanih supstancija u obliku alkoholnih pića u svrhu uživanja. Smatra se da je $50 \%$ zločina i isto toliko saobraćajnih udesa učinjeno pod dejstvom alkohola. Pretjerana upotreba alkohola je treći vodeći uzrok smrtnosti koji se može spriječiti. Oko 2/3 odraslih amerikanca pije alkoholna pića. Omjer muškaraca i žena iznosi oko 4:1. Prevalencija upotrebe alkohola je najveća kod mlađih od 30 godina, a procenjuje se da oko $40 \%$ učenika 8 . razreda uzima alkohol [2]. Reakcija na relaciji disulfiram-etanol nastaje kao posljedica povišenih vrijednosti serumskog acetaldehida, koji nastaje kao proizvod metabolizma etanola $\mathrm{u}$ jetri oksidisanog od strane alkoholne dehidrogenaze. Acetaldehid se putem aldehidne dehidrogenaze oksidiše u jetri (do $90 \%$ ), pri čemu kao proizvod nastaje acetat koji se preko ciklusa trikarbonskih kiselina (Krebsov ciklus) oksidiše do ugljendioksida i vode.

Disulfiram blokira ovaj enzim, te izaziva porast koncentracije acetaldehida u serumu nakon konzumiranja etanola. Posljedična mučnina, vrtoglavica, nagon za povraćanjem kod pacijenata stvaraju odbojnost prema alkoholu. Istovremeno, ova reakcija može da dovede do ekstremne hipotenzije, iznenadne srčane smrti kao i intracerebrallne hemoragije [3, 4].

\section{Prikaz bolesnika}

Tridesetjednogodišnji pacijent je pregledan u Službi hitne medicinske pomoći zbog tegoba u vidu osjećaja lupanja srca i "vreline tijela", glavobolje i malaksalosti. Po dolasku, dobija se anamnestički po- 
datak da je pacijent liječeni alkoholičar, te da je u procesu liječenja disulfiramom. Pacijent navodi da je preparat disulfirama uzeo posljednji put prije $48 \mathrm{~h}$. Na dan dolaska u SHMP, uzeo je veću količinu alkohola (kako navodi "5 flaša piva"). Pola sata po uzimanju alkohola javlja se najprije osjećaj lupanja srca, nedostatak vazduha, slabost i malaksalost, kao i mučnina.

Kliničkim pregledom verifikuje se crvenilo kože po tipu urtikarije koje se javlja u paroksizmima, lokalizovano po koži trupa i nadlaktica. U mentalnom statusu se zapaža izražena agitiranost. Disajni šum uredan, akcija srca ritmična i ubrzana, te sistolni krvni pritisak 90/60 mmHg. Preostali klinički pregled je neupadljiv. Elektrokardiografski se verifykuje sinusna tahikardija, frekvence oko 120/ min, bez znakova za akutni koronarni sindrom.

U SHMP je od laboratorijskih nalaza urađena kompletna krvna slika sa diferencijalnom krvnom slikom koja je bila bez osobitosti kao i vrijednost šećera u krvi koja je bila unutar referentnog opsega.

Tokom pregleda i opservacije pacijent počinje da se žali na izraženu glavobolju, uz napomenu da nije bilo promjena u neurološkom statusu koji bi ukazivali na akutno neurološko zbivanje.

Obzirom na potencijalne, po život ugrožavajuće efekte disulfiramske reakcije, ovakvog pacijenta je bilo neophodno uputiti u bolnicu, radi dodatne dijagnostike i produžene opservacije. Stoga je upućen na viši referntni nivo tj. Univerzitetski klinički centar Banja Luka. Tokom transporta, ordiniran je kiseonik, uspostavljen intravenski put i primenjena infuziona otopina $\mathrm{NaCl}$, kortkosteroidi i analgetik. Pacijent je sve vrijeme bio na kontinuiranom EKG monitoringu.

\section{Diskusija}

Ključan, diferencijalno dijagnostički podatak kod prikazanog pacijenta je upravo upotreba disulfirama. Ovaj lijek je u upotrebi za liječenje hroničnog alkoholizma od 1947. godine [5]. Liječenje se započinje dnevnom dozom od $800 \mathrm{mg}$ disulfirama sa kasnijim smanjivanjem doze na dozu održavanja od 100 do 200 mg dnevno. Kao što je već navedeno, disulfiram je tiuramski derivat koji inhibira drugi korak metabolizma etanola, inhibirajući aktivnost aldehidne dehidrogenaze. Ovo dovodi do akumulacije acetaldehida, koji je izrazito toksično jedinjenje, te razvoja po život opasnog aldehidnog sindroma (AS)
[6-8]. Acetaldehid je mnogo toksičniji od samog etanola i već u relativno malim koncentracijama izaziva veoma burnu simptomatologiju. AS se manifestuje mučninom, nagonom na povraćanje, pulsirajućom glavoboljom, crvenilom kože, a ponekad i bolom u grudima, konvulzijama, intrakranijanom hemoragijom, komom, odnosno stanjem šoka. Blag oblik trovanja acetaldehidom vidi se u toku intoksikacije etanolom (muka i povraćanje), budući da sam etanol ima antiemetičko dejstvo.

Kod jednog dijela populacije postoji genetski polimorfizam $u$ aktivnosti enzima uključenih u metabolizam etanola. Brzi metabolizatori alkohola pri malim količinama etanola dovode do razvoja AS bez prethodnih znakova alkoholne intoksikacije $[9,10]$. Iz prikazanog slučaja, jasno je da je naš pacijent imao razvijenu sliku aldehidnog sindroma. Prilikom pregleda i uzimanja anamneze ključno je bilo poznavanje efekata kao i komplikacija istovremene upotrebe etanola i disufirama. Profil neželjenih dejstava istovremene upotrebe ove dvije supstance je $\mathrm{i}$ iskorišten za liječenje alkoholizma. Disulfiram sam po sebi ne smanjuje želju za alkoholom, niti liječi alkoholnu apstinenciju. Međutim, izrazito neprijatna simptomatologija koja se javlja prilikom ovog kombinovanja, stvara averziju prema alkoholu. Ovaj lijek u terapiju uključuju psihijatri i jako je važno da pacijent bude upoznat sa mogućim posljedicama njegovog uzimanja. Svakako je ključna produžena opservacija ovih pacijenata, jer iako u većini slučajeva uzimanje alkohola $\mathrm{u}$ toku liječenja disulfiramom prolazi "samo" sa neprijatnom simptomatologijom, ponekad može da dođe do po život ugrožavajućih komplikacija. To su koma, intracerebralna hemoragija, naprasna srčana smrt kao i akutni infarkt miokarda. Zbog navedenih potencijalnih komplikacija i njihove simptomatologije neophodan je hospitallni tretman.

U prehospitalnom zbrinjavanju indikovano je ordinirati kiseonik, obezbijediti venski put i priključiti pacijenta na monitor. Kod pacijenata sa izmjenjenim mentalnim statusom ordinirati glukozu, tiamin i nalokson. Kod hipotenzije, tahikardije i profuznog povraćanja potrebno je uključiti infuzione otopine. Ako je pacijent u komi ili sa teško izmjenjenim mentalnim statusom, neophodno ga je intubirati da bi se obezbjedila adekvatna ventilacija plu- 
ća, ali i prevenirala aspiracija povraćanog sadržaja [11]. Pojedini lijekovi izazivaju tzv. Disulfiramu, sličnu reakciju, što treba imati u vidu u smislu edukacije pacijentu kao neželjenu reakciju na lijek, kao i upoznati pacijenta sa koefektima tih lijekova u kombinaciji sa alkoholom. Lijekovi koji mogu biti potencijalni okidači neželjenih reakcija su najčešće: metronidazol, ketokonazol, tinidazol, trimetoprimsulfometoksazol, izosorbid dinitrat, nitroglicerin, pojedini preparati sulfonilureje. [12,13].

\section{Zaključak}

Već na prehospitalnom nivou, potreban je ozbiljniji pristup pacijentima koji se liječe od alkoholizma. U tom cilju, neophodna je edukacija ljekara u SHMP o poznavanju efekata kombinovanja alkohola sa disulfiramom, ali i u kombinaciji sa drugim lijekovima, kao osnovni preduslov za uspješno liječenje i sprečavanje komplikacija. Takođe, prije uvođenja disulfirama treba upoznati pacijenta sa potencijalnim neželjenim efektima u slučaju kombinacije alkohola i disulfirama.

Informisani pristanak: Dobijena je saglasnost bolesnika za objavljivanje ovog rada.

Sukob interesa: autori izjavljuju da nemaju sukob interesa.

\section{LITERATURA}

1. Yoshimura A, Kimura M, Nakayama H, Matsui T, Okudaira F, Akazawa S, et al. Efficacy of disulfiram for the treatment of alcohol dependence assessed with a multicenter randomized controlled trial. Alcohol Clin Exp Res. 2014;38(2):572-8. doi: 10.1111/acer. 12278. PMID: 24117666.

2. Witkiewitz K, Litten RZ, Leggio L. Advances in the science and treatment of alcohol use disorder. Sci Adv. 2019;5(9):eaax4043. doi: 10.1126/sciadv. aax4043. PMID: 31579824.

3. Leggio L, Falk DE, Ryan ML, Fertig J, Litten RZ. Medication Development for Alcohol Use Disorder: A Focus on Clinical Studies. Handb Exp Pharmacol. 2019. doi: 10.1007/ 164_2019_295. PMID: 31628604.

4. Leggio L, Falk DE, Ryan ML, Fertig J, Litten RZ. Medication Development for Alcohol Use Disorder: A Focus on Clinical Studies. Handb Exp
Pharmacol. 2019. doi: 10.1007/ 164_2019_295. PMID: 31628604.

5. LiverTox: Clinical and Research Information on DrugInduced Liver Injury [Internet]. Bethesda (MD): National Institute of Diabetes and Digestive and Kidney Diseases; 2012-. Disulfiram. [Updated 2018 Jan 5]. Bookshelf URL: https://www.ncbi. nlm.nih.gov/books/

6. Varagić VM, Milošević MP. Farmakologija, 23. izdanje. Beograd: Medica Graf, 2012.

7. Vasović V, Mikov M, Đaković-Švajcer K. Odabrana poglavlja iz toksikologije, 2. izdanje. Kula: Borac. 2009.

8. Karamanakos PN, Pappas P, Boumba VA, Thomas C, Malamas M, Vougiouklakis T, et al. Pharmaceutical agents known to produce disulfiramlike reaction: effects on hepatic ethanol metabolism and brain monoamines. Int $\mathbf{J}$ Toxicol. 2007; 26(5):423-32. DOI:10.1080/ 10915810701583010. PMID: 17963129.

9. Thompson A, Ashcroft DM, Owens L, van Staa TP, Pirmohamed M. Drug therapy for alcohol dependence in primary care in the UK: A Clinical Practice Research Datalink study. PLoS ONE. 2017; 12(3): e0173272. Available at: https://doi.org/ 10.1371/journal.pone. 0173272.

10. Sogholan S, Wiener SW, Tarabar A. Disulfiram Toxicity Treatment \& Management. http: //emedicine.medscape.com/article/814525-treatment\#d10 11. Le Daré B, Lagente V, Gicquel T. Ethanol and its metabolites: update on toxicity, benefits, and focus on immunomodulatory effects. Drug Metab Rev. 2019;51(4):545-61. doi: 10.1080/ 03602532. 2019.1679169. PMID: 31646907.

12. Holton EA, Gallagher P, Fahey T, and Cousins G. Concurrent use of alcohol interactive medications and alcohol in older adults: a systematic review of prevalence and associated adverse outcomes. BMC Geriatr. 2017; 17: 148. doi: 10.1186/s12877-0170532-2. PMID: 28716004

13. Ahacic K, Kennison FR, Kåreholt I. Alcohol abstinence, non-hazardous use and hazardous use a decade after alcohol-related hospitalization: registry data linked to population-based representative postal surveys. BMC Public Health. 2014; 14: 874. Published online $2014 \quad$ Aug 24. doi: 10.1186/1471-2458-14-874.PMID: 25150844 . 
- $\quad$ case report -

\title{
DISULFIRAM REACTION
}

Nada BANJAC, Boris DOJČINOVIĆ

Emergency Medical Aid Department and Educational Center, PHI Community Health Center, Banja Luka, Republika Srpska, Bosnia and Herzegovina

\begin{abstract}
Disulfiram is a drug used for treating chronic alcoholism. The disulfiram-ethanol reaction is a result of increased blood levels of acetaldehyde, which is the product of alcohol dehydrogenase induced ethanol oxidation in the liver. Acetaldehyde is a toxin, which is broken down by acetaldehyde dehydrogenase to acetic acid, which is then eliminated from the body. Disulfiram inhibits the enzyme acetaldehyde dehydrogenase, therefore causing the increased concentration of blood acetaldehyde after ethanol consumption, which results in ill effects of ethanol, nausea and vertigo. We are presenting a case of a 31 year-old patient who was treated with disulfiram for chronic alcohol abuse. Half an hour before being admitted for examination at the Emergency Medical Aid Department he had ingested a large quantity of alcohol. Upon examination, based on the following symptoms: agitation, tachycardia, hypotension, skin erythema with hives, the diagnosis of disulfiram reaction was made. He was referred and transported to the University Clinical Center Banja Luka for further evaluation and observation. During transport, he was treated with oxygen, i.v. fluids, corticosteroids and analgesics. He was attached to a ECG monitor. Emergency Medical Aid doctors must be educated to recognize and initially treat patients with disulfiram reaction.
\end{abstract}

Key words: alcoholism, disulfiram, acetaldehyde. 